\title{
Zoomorphic Culture Code as a Device of Human Appearance Conceptualization in the Bulgarian and Russian Linguocultures
}

\author{
As Exemplified in Figurative Comparisons
}

\author{
Radostina Stoyanova \\ University of Economics \\ Varna, Bulgaria \\ E-mail: r.stoyanova@ue-varna.bg
}

\begin{abstract}
The paper examines the zoomorphic culture code as a device of human appearance conceptualization in the Bulgarian and Russian linguocultures. The comparative study of Bulgarian and Russian figurative comparisons, representing human appearance, has identified the following relationship types: the relationship of complete equivalence; the relationship of structurally similar but semantically different figurative comparisons; the coincidence of the tertium comparationis against the discrepancy of chosen reference standards; and the dissimilarity of the tertium comparationis and the corresponding reference standard. The zoomorphic culture code, as part of the linguistic world landscape, reflects the value system of the Bulgarian and Russian linguocultures.
\end{abstract}

Keywords-zoomorphic culture code; figurative comparisons; appearance; Bulgarian language; Russian language

\section{INTRODUCTION}

The present paper flows organically from the author's work aimed at the description of zoomorphic figurative comparisons conveying human appearance, as well as from the work addressing the zoomorphic culture code in the semantics of Bulgarian and Russian zoomorphic comparisons [1] [2].

The material for this work has been selected using continuous sampling from the lexicographic publications of B. Yanev1, K. Ankova-Nicheva2, K. Nicheva, S. SpasovaMikhailova and K. Cholakova3, A. K. Koshelev and M. A.

B. Yanev, Figurative comparisons with anthropocentric nature in the Bulgarian and English languages (research and dictionary). Plovdiv: "Paisius of Hilendar" University Press, 2013, 370 p.

K. Ankova-Nicheva, New phraseological dictionary in Bulgarian, Sophia: "Sveti Kliment Okhridski” University Press, 1993, 462 p.

Phraseological dictionary in Bulgarian, vol. 1, A - N. / Contr. K. Nicheva, S. Spasova-Mikhailova, Kr. Cholakova. Sophia: Bulgarian Academy of Sciences publication, 1974, Vol. I, 760 p.

Phraseological dictionary in Bulgarian, vol. 2. O - Ya. / Contr. K. Nicheva, S. Spasova-Mikhailova, Kr. Cholakova. Sophia: Bulgarian Academy of Sciences publication, 1975, Vol. II. 780 p.
Leonidova4, L. A. Lebedeva5, V. M. Mokiyenko6, V. M. Ogoltsev7 and R. Holandi8, and as the electronic Internet contributions of different genres.

Code presents the main notion of the semiotics, science about signs and sign processes. As a term of semiotics code means the law of correspondence between the plane of expression and the plane of content. Code assigns sign's significance, while the interpreter defines that significance, "decodes", namely understands the sign. In the formal sense, the significance is perceived as a quality of the system element to have weight or content, which are evaluated by the system users according to a specific scale [3].

In semiotics, code also means the class of signs and the rules of their "decoding" by the interpreter, which are conditioned by one or another knowledge, by one or another culture, wherein they will be decoded, by one or another chronotope, the interpreter's competence, etc. Therefore, semiotics determines the sign, its significance (its ability to have content), and the code through which the significance is set and through the connection to which the interpreter can understand the sign and decode its content [4].

According to E. S. Kubryakova, "the ability to interpret things and situations as signs and hence to understand the world not only at the external, material, sensory-motor level, vividly indicates that the very process of understanding the

A. K. Koshelev, Bulgarian-Russian phraseological dictionary / Contr. A. K. Koshelev, M. A. Leonidova - M.: Russian Language; Sophia: Science and Art, 1974, 635 p.

L. A. Lebedeva, Sustained comparisons of the Russian language: thematic dictionary / L. A. Lebedeva, Second edition, M.: FLINTA: Science, 2015, $316 \mathrm{p}$.

V. M. Mokiyenko, The Great Dictionary of Russian folk comparisons / V. M. Mokiyenko, T. G. Nikitina; edited by V. M. Mokiyenko. M.: ZAO OLMA Media Group, 2008, 800 p.

V. M. Ogoltsev, Dictionary of sustained comparisons of Russian (synonymous -antonymic), M.: OOO Russian Dictionaries” Astrel Publishing: AST Publishing House, 2001, 800 p.

R. Holandi, Sustained comparisons: Russian, Bulgarian, English, German, French. - Blagoevgrad: South-West University Press "Neofit Rilski”, 2008. 472 p. 
world presents an inferential process, besides it requires the semiotic competence of people" [5].

Further, according to Yu.S. Stepanov, the semiotics "finds its objects everywhere - in language, mathematics, literature, in a separate piece of fiction, in architecture, apartment layout, in a family arrangement, in the processes of the unconscious, communication between animals, in plant life" [5]. At the same time, language presents the basic, universal code for man's semiosphere. Language is the main subject of semiotics, and the linguistic sign, consequently, can be considered as the main medium of expression, or exteriorization, meaning. Any semiotic system (of symbol, dance ritual and other) can be transferred into the language system. It is language that presents the optimal means of expressing values, including the values of other sign systems. From this point of view, language is examined in various concepts, such as, for example, the concept of semiosphere, namely the semiotic universe, the space wherein communicative processes are realized and new information forms. The linguistic sign is qualified as the main medium of expression of meaning. [6].

\section{The CONCEPT “CUlture CODE”}

\section{A. Culture Code}

Code forms and functions in culture. M.L. Kovshova defines culture as a semiotic system where signs and meanings synthesize: sign is the carrier of what has been developed by man in the process of his world perception [6].

Culture presents "the space of cultural meanings, or value content, formed by man during perception, and codes - the secondary sign systems where different material and formal means are used for denotation of cultural meanings. Differently coded value content, produced in culture, forms a system of culture codes and generally composes the picture of the world that interprets the world outlook of one or another society" (underlined by M.L. Kovshova) [6].

Inside the culture system its codes are getting organized and hierarchically ordered-the secondary sign systems, realizing different material and formal means to encode the same cultural content, uniting at large in the world landscape, in the mindset of that society. By this the concept culture code differs from code, which is the basic concept of semiotics [6].

From the perspective of V.V. Krasnykh, the concept 'culture code' is understood "ambivalently depending on what the attention is more focused on" [7]. For purposes of culture, the concept 'culture code' is understood as "a net" that culture "throws upon" the outside world and thanks to which man splits, evaluates, categorizes, structures the world and comprehends himself in this world [8] [9]. For purposes of linguistics, the concept 'culture code' is regarded as the whole of names and their combination, having, beside the denoting meaning as such, the cultural meanings [10].

V. N. Telia treats the concept of culture code not as the whole of signs of different material nature but as the whole of their domesticated concepts - 'code of culture' is a taxonomic substrate of its texts. That substrate constitutes one or another body of a certain society's domesticated vision of the worldview - included into it natural objects, artefacts, phenomena, identifies in it actions and developments, mentafacts and incident to those entities their spatial-time and qualitative-quantitative dimensions. For instance, the physical or actional code of ritual behavior patterns, the cosmologic or zoologic, in particular, the animal, myth code, the code of Christianity, the code of 'ideologemes' of romanticism or social realism, etc. The cumulative-genetic nature of conscience keeps in its domesticated collective memory those codes and the sense of taxons forming them [11]. V. N. Telia demarcates the cultural function of that or another culture-specific concept from the cultural function of that concept's name, since "the word meaning in this instance is endowed with the sense, indicating not the own reference of the word, but associatively 'substitutes' a certain idea”.

In her typology of culture codes V. N. Telia takes as a beginning point not the signs of various substances (artefacts, actions and such), but their nominations, i.e. the signs of once verbal substance. Pursuant to V. N. Telia's understanding, the anthropic culture code presents a set of man's nominations in his many capacities, the zoomorphic code presents a set of animal names and so on and so forth.

V. V. Krasnykh defines culture code from the perspective of pshycho-linguoculturology, following on from the ideas of V. N. Telia: "C u l t u r e c o d e is a set of mentafacts forming certain fragment of the world landscape, pertaining to the phenomena with cultural contexts, relevant to one type and / or one scope of existence. Names of the latter carry further to the basic meanings that reflect the nature of referred phenomena, the contexts functionally significant for culture (V. N. Telia). This preconditions those mentafacts' functioning as reference standards, symbols and presentative foundations of metaphors and thus allows considering their names as the field of the signs of culture 'language', namely assigns those names the role of linguoculture signs" (italics of V.V. Krasnykh) [12].

V.V. Krasnykh points also to the existence of "basic" and "non-basic" codes of culture. More ancient and larger and, hence, more significant codes are forming a narrower circle of culture codes. V.V. Krasnykh assigns to those the somatic code and the codes pertaining to nature - to the animal and floral world, to the elements. He explains this by the fact that man began to explore the surrounding world from what was closer to him - his own body and from was surrounding his everyday life [13].

To the basic codes for Russian culture V. V. Krasnykh assigns as follows: anthropic, to which the somatic / corporal code refers; biomorphic, including zoomorphic (within which particularly come forth zoomorphic, associated with animals; insective, associated with insects; codes associated with birds, fish and other; and vegetative / botanical, wherein there are the arboretum, associated with trees and bushes, and the floral codes, associated with flowers and herb); natural-elemental; temporal; spatial; artefactual / presentive; 
numerological; coloristic; actional and spiritual code of culture [13].

\section{B. Zoomorphic Culture Code}

Zoomorphic culture code presents an interesting, original linguistic layer, identifying the specifics of world perception of different linguocultures' representants. Different definitions of the zoomorphic culture code can be met in the linguistic literature. In the opinion of V. V. Krasnykh, the zoomorphic culture code is "the set of cultureconditioned stereotype beliefs about the qualities, characteristics or special aspects of animals' behavior that act as a source of understanding by man of the world and in addition to their natural properties carry senses functionally significant to culture" [14].

L. V. Savchenko includes into the concept "zoomorphic culture code" "the names denoting objects of wildlife and their partitive elements, also the properties and actions, assigning to those names the role of signs of culture "language" [15]. The scholar considers that the world of bestiaries, existing on the edge of two worlds, should not be included into the zoomorphic culture code. Savchenko offers the term zoomorphic culture code "inasmuch as it reflects the integrity of notions about the wildlife, whose representants or their partitive elements fulfill functions of reference standards in culture" [15].

V. A. Maslova and M. V. Pimenova defines the zoomorphic code as "a series of images and symbols of culture that includes the characters of animals (animalisms), birds (ornithisms), fish (ichthyisms) and insects (entoisms)" [16].

\section{ZOOMORPHIC FIGURATIVE COMPARISONS}

Images of animals represent the largest number of images that man associates with the idea of his appearance. Comparisons, just as figurative comparisons, being a product of associative thinking, appeared in oral speech. Observations over animals' appearance had led to the emergence of stereotypical concepts of animals themselves in the capacity of archetypes that are carried over to the characteristics of human appearance in the form of zoomorphic figurative comparisons. Stereotype visions are the primary phenomenon in man's subcultural space.

The first figurative comparisons, more likely, are the result of visually perceived appearance. Probably, since before man explored animals' behavior and their mode of life, he had associations with their appearance [17].

Figurative comparison usually has a triple-component model:

- Subject of thought (man is the compared object).

- Tertium comparationis (the feature, common to man and animal).

- Standard (image) of comparison (the animal as carrier of a certain feature).
Between the tertium comparationis (feature) and the standard (image) there is a "comparative form word" (comparative preposition kato9, less commonly - kato che li, syakash (kato da), comp. Rus. conjunction kak (as), less commonly slovno, budto, tochno (as if, allegedly, like), which turns the comparison into a linguistic fact. The Russian language also has conjunctionless comparisons where a noun is in the instrumental case: Rus. golova / $u$ kogo/ iaitsom (golova /u kogo/ kak iaitso (lit. an egg-like head).

The Bulgarian and Russian linguocultures show figurative comparisons representing various parts of animals: Bulg. lek kato pero / pertse (perushina / perushinka) (lit. as light as a feather (flock) - Rus. legkii kak pero / peryshko (pushinka / pushinochka, pukh) (lit. as light as a feather /flock, floccus/), Bulg. cheren kato krilo na garvan (about hair) (lit. as black as a raven wing) - Rus. lit. as black as a raven wing 'very blackish', as black as a raven.

Selection of the images of comparison in each linguoculture had been carried out for an extended period and became stable in certain languages, reflecting various aspects of a nation's cultural and historical development.

\section{REPRESENTATION OF ZOOMORPHIC CULTURE CODE BY BULGARIAN AND RUSSIAN ZOOMORPHIC FIGURATIVE COMPARISONS}

The coincidence or mismatch of the tertium comparationis and standards (images) in the comparative structures of comparable languages depends on the representations, assigned to each animal in the linguistic consciousness of those languages' speakers.

Zoomorphic culture code in the semantics of Bulgarian and Russian zoomorphic figurative comparisons reflects various aspects of human appearance. Here are some of them:

\section{A. Face}

To convey properties of man's non-standard, plain face form the Russian language uses comparisons with the zoolexemes horse, pig and ape: Rus. litso (fizionomiia) /u kogo/ kak u loshadi 〈dlinnoe> (lit. a <long> horse-like face (physiognomy) /disappr./); Rus. kak loshadinaia morda (lit. like a horse face); Rus. rylo kak u svin'i (lit. snout like of a pig); Rus. litso kak u obez'iany (lit. ape-like face).

The Bulgarian and Russian comparisons also fix the attribute of complexion: Bulg. byal kato galab (lit. as white as a dove); Bulg. byala kato patka (lit. as white as a duck); Bul. byal kato gaska (lit. as white as a goose); Bulg. zhalt kato papunyak (lit. as yellow as a hoopoe); Bulg. cherven kato <varen> rak (lit. as red as a <boiled> crab); Bulg. zachervil se kato rak (lit. redden as a crab); Bulg. izchervyavam se (pochervenyavam, zachervya se) kato <varen> rak (lit. to blush (turn red, flush) as a <boiled> crab); Bulg. cheren kato garvan (lit. as black as a raven); Bulg. cheren kato krilo na garvan (lit. as black as raven's

\footnotetext{
${ }^{9}$ In Bulgarian linguistics the form word kato inside the comparative construction is regarded as a preposition, while in Russian as a conjunction.
} 
wing); Bulg. sin kato puycha glava (lit. as blue as turkey's head) /dial./; Rus. krasnoe (pokrasnet') kak <varenyi > rak (lit. as red (to redden) as a <boiled> lobster); Rus. chernyi (pochernet') kak voron (lit. as black (to grow black) as a raven); Rus. chernyi kak zhuk (lit. as black as a beetle); Rus. chernyi kak grach (lit. as black as a rook); Rus. chernaia kak galka (lit. as black as a jackdaw); Rus. seryi kak zhaba (lit. as grey as a toad). To describe a white freckled face the Russian language uses the following comparisons: Rus. litso $u$ kogo <pestroe> kak ptichye yaitso (lit. face <spotted> like bird's egg /colloq., ironic/); Rus. litso u kogo kak voron'e iaitso (lit. face like crow's egg /colloq., ironic/). Sombre or dark complexion, especially of a girl or a woman, is compared to the eider-duck and the loon (a large water bird with rich black feathering, member of the loon family: Rus. chernyi kak gaga (lit. as black as an eider /dial., disappr./); Rus. chernyi kak gagara (lit. as black as a loon /dial., disappr. /); Rus. zagorelyi (nagorevshiy) kak gagara (lit. tanned like a loon). At the same time, the Russian language conveys a pink and pure skin through the comparison rozovyi kak porosenok (lit. as pink as a piggy /humor./). The beauty of a girl's face is described with the help of the comparison of folk origin kak lebedka belaia (lit. like a white female swan /dial., folk., sympath. /).

\section{B. Eyes}

To mark out protruding eyes in the Bulgarian linguoculture the authors have discovered the following comparisons: Bulg. ochi kato na bivol (lit. eyes as buffalo's eyes); Bulg. ochi kato na zhaba (lit. like frog's eyes); Bulg. opulyam ochi kato varen zayek /dial./ (lit. to pop eyes out like cooked hare); Bulg. opulyam ochi kato vol /dial./ (lit. to pop eyes out like an ox); Bulg. opulil sam se kato petel na dazhd /dial./ (lit. widened eyes like a rooster at rain); Bulg. opulil ochi kato zhabche v tinya /dial./ (lit. to widen eyes like a frog in ooze). The Bulgarian linguoculture conveys the peculiarities of human look through the zoomorphic figurative comparisons, the first part of which has the verb gledam (to look): Bulg. gledam (migam) kato tele (lit. to look like a calf).; Bulg. gledam kato ovtsa (lit. to gaze like a sheep); Bulg. gledam kato vol (lit. to gaze like an ox); Bulg. gledam kato krava (lit. to gaze like a cow); Bulg. gledam kato tele pred gramotevitsa (lit. to look like a calf before thunder); Bulg. gledam kato bivol pred nova porta /iron./ (lit. to look puzzled like a buffalo at new gates); Bulg. gledam kato tele pred (v) zheleznitsa /iron./ (lit. to look puzzled like a calf at a railroad); Bulg. gledam kato tele pred (v) ikonostas /iron./ (lit. to look puzzled like a calf at iconostasis); Bulg. gledam kato tele pred (v) sharena vrata /iron./ (lit. to look puzzled like a calf at a painted door); Bulg. gledam kato tele u ornitsa /dial., iron./ (lit. to look like a calf in a room); Bulg. gledam kato biyen plah /dial./ (lit. to look like a beaten rat); Bulg. gledam kato svinya na sekira (lit. to look like a pig at poleaxe); Bulg. gledam kato ubodeno shile /dial., ironic/ (lit. to look like bitten by bodkin); Bulg. gledam kato garmyan bik /ironic/ (lit. to look like a threatful bull); Bulg. gledam kato nastapena zhaba (lit. to look like a hurt toad); Bulg. gledam kato mlado yare na nov snyag /ironic/ (lit. to gaze like a baby-goat at fresh snow); Bulg. gledam kato natratena mishanka /dial./ (lit. to look like a tired mouse);
Bulg. gledam kato kuche na yakudi slivi (lit. to stare like a dog at plums); Bulg. gledam kato koza v kalendar (lit. to stare like a goat at calendar).

Through the zoomorphic figurative comparisons the Russian language offers a richer scale of human eyes' traits-eye colors (Rus. glaza kak u koshki zelenye (zheltye) (lit. catish green (yellow) eyes); Rus. glaza kak u rysi zheltye (lit. yellow eyes like a lynx); Rus. glaza kak u krolika /krasnye/ (lit. red eyes like a rabbit 'sharpness of sight and special look'); Rus. glaza kak u sokola (lit. eyes like a falcon); Rus. glaza kak u iastreba (lit. eyes like a hawk); Rus. glaza kak u kobtsa (lit. eyes like a red-footed falcon); Rus. (zrenie) kak u koshki (lit. cat's sight); Rus. kak u iastreba kruglye (khishchnye, zorkie) (lit. the round (raptorial, sharpsighted) eyes like a falcon); Rus. kak u korshuna zorkie (khishchnye, derzkie) (lit. sharp-sighted (raptorial, daring) eyes like a kite); Rus. glaza kak u berkuta (lit. eyes like a golden eagle); Rus. videt' kak sova (lit. to see like an owl); Rus. zrenie (glaza) kak u koshki (lit. cat-like eyes); Rus. zrenie kak u orla (lit. an eagle-like sight); Rus. zrenie kak $u$ sovy (lit. an owl-like sight); Rus. zrenie kak u iastreba (lit. a falcon-like sight); Rus. blizkozoryi kak sova (lit. shortsighted like an owl /dial., disappr./); Rus. smotret' (gliadet') sokolom = smotret' kak sokol (lit. to look as a falcon); Rus. glaza kak (slovno, tochno) u koshki blestiat (sverkaiut, svetiatsia, goriat) (lit eyes shoot fire like a cat); Rus. glaza kak u kota svetiatsia, sverkaiut, blestiat (v temnote) (lit. gleaming eyes like cat in the dark); Rus. sverknut' (blesnut') glazami kak rys' (lit. to gleam eyes like a lynx); Rus. blestet' kak volchii glaz (lit. to glare like wolf's eye); Rus. blestet' kak volka glaz (lit. to glare like wolf's eye); Rus. glaza kak u volka /volchitsy/ (lit. eyes like a wolf /she-wolf); Rus. vzgliad kak u kota (lit. eyes like a cat); Rus. glaza u kogo kak u kota (lit. smb who has eyes like a cat /disappr./); Rus. smotret' (gliadet') kak sova <vypuchiv glaza> (lit. to stare (look) like a <goggle-eyed>owl /ironic./); Rus. smotret' kak sova iz duba (lit. to look like an owl from an oak /slang, dial., ironic/); Rus. vzglyad kak u sokola (lit. a falcon-like look); Rus. vzglyad kak u iastreba (lit.a hawk-like look); Rus. smotret' kak baran na novye vorota (lit. to stare like a buck at a new gate); Rus. smotret' kak baran na vodu (lit. to stare like a buck at water /folk., ironic./); Rus. smotret' kak koza v afishu (lit. to look like a goat at a playbill); Rus. smotret' (vylupit'sia, vylupit' glaza) kak baran $\langle v$ potolok $>$ (lit. to look (protrude) like a sheep <at ceiling>); the expression and form of eyes (Rus. glaza kak u loshadi (lit. horse eyes); Rus. glaza kak u barana (lit. sheepish eyes); Rus. glaza kak u vola (lit. bull-like eyes); Rus. glaza kak u kozy (lit. goat-like eyes); Rus. glaza kak u korovy (lit. cowish eyes); Rus. glaza kak u kota (lit. cat eyes); Rus. glaza 〈svetiatsia> kak $u$ koshki (lit. eyes < glowing> like cat's); Rus. glaza kak u lani (lit. eyes like a fallow deer); Rus. glaza kak u orla (lit. eyes like an eagle); Rus. glaza kak u ryby (lit. sih-like eyes); Rus. glaza kak u rysi (lit. eyes like a lynx); Rus. glaza kak u khishchnika (lit. raptor's eyes); Rus. glaza kak u beshenoi korovy (lit. mad cow eyes); Rus. vypuchennye (vypuklye, navykate) kak u raka (lit. wall eyes (bulgy) like lobster's). 


\section{Eyebrows}

The Bulgarian and Russian linguocultures associated eyebrows with the leech (Bulg. vezhdi kato<morski> piyavitsy /it. eyebrows as <sea> leeches/), and the fawn (Rus. broven'ki /u kogo/ kak kozochki) 'eyebrows like fawns /pet form, dial. appr. /), correspondingly.

\section{Hair}

Zoomorphic figurative comparisons in the Bulgarian and Russian linguocultures also underline the special aspects of hair, which are more widely represented in the Russian language:- Bulg. kosa ostra kato chetina (lit. the plait sharp as bristle); Bulg. byal kato gaska (lit. as white as a goose); Bulg. roshav kato garga (lit. shaggy like a crow); Bulg. pobelyal kato ovtsa (lit. as white as a sheep); Bulg. kadrav / kadrava kato pudel (lit. curly as poodle); Rus. kudriavyi, (kucheriavyi, zavitoi) kak baran (barashek) (lit. curly (waved) like a sheep /lamb/); Rus. kudriavye (kurchavye, zavitye) kak u barashka (barana) (lit. as curly (waved) as a lamb /sheep/); Rus. kudriavyi, (kucheriavyi, zavitoi) kak pudel' (lit. curly (waved) like a poodle); Rus. volosy kak pukh (lit. hair like floccus); Rus. visyat konskim khvostom ( lit. hand like horsetail); Rus. pegii kak korova (lit. dapple like a cow /dial./); Rus. volosy u kogo kak korova zalizala (lit. hair as if slicked by a cow /dial., jok./); Rus. volosy u kogo kak kotenok (koshonok) zalizal (lit. hair as if slicked by a kitten /dial., jok./); Rus. zhestkie kak $<$ konskaya> griva (lit. coarse hair like <horse>mane); Rus. zhestkie kak shchetina (lit. as hard as bristle); Rus. bel/bela kak lun' (lit. as white as a harrier); Rus. sedoi kak lun' (lit. as grey as a harrier); Rus. ryzhaya kak belka (lit. as red as a squirrel); Rus. ryzhaya kak lisa (lit. as red as a fox); Rus. volosy belye (sedye, svetlye) kak lun' (lit. white hair (grey, fair) like a harrier); Rus. volosy chernye kak voronovo krylo (lit. black hair as crow's wing); Rus. volos'ia u kogo kak u martovskogo kota (lit. hair like a March cat /dial., iron./).

\section{E. Nose}

In the lexicographic publications only Russian zoomorphic figurative comparisons, conveying the features of the human nose, were found-Rus. nos <kriuchkovatyi > kak u iastreba (lit. <hooknose> like a hawk); Rus. nos kak u iastreba kriuchkom (zagnut vniz, vnutr') (lit. hawknose); Rus. nos kak u filina kriuchkom (zagnut vniz, vnutr') (lit. hooknose like eagle-owl /deflexed/); Rus. nos dlinnyi kak khobot (lit. a long nose like a trunk /iron./); Rus. nos kak u orla krupnyi (lit. a big nose like of an eagle); Rus. nos kak u orla kriuchkom (lit. a hooked nose like hawknose).

\section{F. Cheeks}

The Bulgarians and the Russians compare jowls with those of a bulldog-Bulg. buzi kato na buldog (lit. cheeks like a bulldog's) - Rus. shcheki kak u bul'doga obvislye (obvisnut') (lit. bulldoggish jowls /to sag/). Russian lexicographic sources also have the following comparisons-Rus. rozovoshchekii kak porosenok (lit. rosycheeked like a piggy /jok./); Rus. shcheki kak u khomiaka/khomiachka tolstye (lit. cheeks like a hamster).

\section{G. Teeth}

In the Bulgarian and Russian linguocultures big teeth are associated with horse teeth-Bulg. golemi kato na kon (lit. as big as a horse) - Rus. krupnye (bol'shie) kak u loshadi (lit. horse-like big); Rus. zuby kak u khor'ka ostrye (melkie) (lit. polecat-line sharp (small) teeth).

\section{H. Moustache}

In the materials collected by us, only Russian zoomorphic figurative comparisons were found with the characteristics of human mustache-Rus. usy kak $u$ kota (lit.cat moustache); Rus. usy kak u morzha (lit. walrus-like moustache); Rus. usy kak u tarakana (lit. cockroach-like moustache); Rus. chernye kak voronovo krylo (lit. as black as a crow wing).

\section{Mouth}

The zoomorphic figurative comparisons describing the peculiarities of man's mouth are also found only in the Russian lexicographic publications-Rus. rot kak u liagushki (lit. frog-like mouth); Rus. rot kak u zhaby (lit. a toad-like mouth); Rus. rot kak u shchuki (lit. a jackfish-like mouth); Rus. rot kak u soma (lit. a catfish-like mouth); Rus. rot kak u nalima (lit. a dogfish-like mouth).

\section{J. Ears}

The zoomorphic figurative comparisons conveying patterns of human ears are present both in the Bulgarian and Russian lexicographic sources-Bulg. klepnali mu ushite kato na magare (lit. he has sticking ears like a donkey); Bulg. klepnali mu ushite kato na darta svinya (lit. he has sticking years like a pig); Rus. ushi kak u osla (lit. donkey-like ears).

\section{K. Beard}

In the Bulgarian linguoculture beard is associated with a sharp bristle-Bulg. ostra kato chetina (lit. as sharp as bristle). The Russian linguoculture singles out such attribute as "beard color"-Rus. chernaia kak voronovo krylo (lit. as black as crow wing); Rus. sedaia kak lun' (lit. as grey as harrier).

\section{Hands, fingers, palms}

The zoomorphic figurative comparisons describing the peculiarities of human hands, fingers or palms are fixed only in the Russian lexicographic sources-Rus. kak kleshchi tverdye (tsepkie, sil'nye) (lit. as hard as pincers /prehensile, strong/); Rus. dlinnye kak u gorilly (lit. as long as gorilla's); Rus. krasnye kak gusinye lapy (lit. as red as duck feet); Rus. kak u gusia/gusyni 〈lapy> krasnye (lit. goose-like red $<$ feet>); Rus. kak u orangutana (lit. as of orangutan), Rus. nekrasivye kak u obez'iany (lit. ugly as a monkey).

\section{Feet}

The zoomorphic figurative comparisons conveying the peculiarities of human feet can be found only in the Russian lexicographic sources-Rus. krasnye kak u gusia/gusyni $<$ lapy>, krasnye kak gusinye lapy (as (lit. red as goose feet); Rus. as long as crane (lit. dlinnye kak u zhuravlia); Rus. 
tolstye kak u slona (lit. as fat as of elephant); Rus. nogi kak u kobyly (lit. mare-like feet /dial./); Rus. horse-like thighs /dial./); Rus. nogi kak u lani (lit. legs as of a fallow deer /bookish-poetic/); Rus. nogi kak u gazeli (lit. feet as of gazelle).

\section{N. Neck, back of the head}

There is just one zoomorphic figurative comparison in the Bulgarian lexicographic sources associated with bull's neck-Bulg. vrat kato na bik (lit. neck as bull's neck). Zoomorphic figurative comparisons of the Russian linguoculture are richer with superfine details describing the human neck-Rus. kak u gusia dlinnaia (tonkaia) (lit. as long (thin) as of a goose); Rus. kak u zhirafa dlinnaia (tonkaia) (lit. as long (thin) as of a giraffe); Rus. kak u byka tolstaia (moshchnaia) (lit. as long (beautiful) as swan neck); Rus. kak u bugaia tolstaia (moshchnaia) (lit. bull neck); Rus. vytiagivat' (tianut') sheiu kak zhiraf (lit. to make (rubber) a long neck like a giraffe /iron./); Rus. zatylok kak u byka (lit. bull back of neck); Rus. zatylok kak $u$ vola (lit. ox back of the head). At the same time, the Bulgarian and Russian linguocultures associate fine human neck with a swanneckBulg. shiya kato na lebed (lit. swanneck), compare also Bulg. s lebedova shiya (lit. with swanneck) - Rus. dlinnaia (krasivaia) kak u lebedia sheia (lit. as long (fine) as swanneck).

\section{O. Nails}

Only Russian lexicographic sources have zoomorphic figurative comparisons describing the peculiarities of human nails-Rus. ostrye kak u koshki (lit. as sharp as cat's); Rus. kogti kak u koshki (lit. cat-like claws).

\section{P. Back}

Zoomorphic figurative comparisons, characterizing human back, are met only in the Russian lexicographic sources-Rus. spina kak u ryby (lit. fish-like back).

\section{Q. Waist}

Also, only the Russian figurative comparisons describe man's slender waist-Rus. kak u osy <tonkaia > taliia (lit. as slender as wasp waste); Rus. tonkaia <v talii > kak osa (lit. as thin <in waist> as wasp); Rus. tonkii kak osa (lit. as slender as wasp).

\section{R. Body}

\section{1) Obesity, fatness}

In the Bulgarian and Russian linguocultures, zoomorphic figurative comparisons, describing man's chubbiness or fattiness are very widely represented-Bulg. debel kato bik (lit. as fat as a bull); Bulg. debel kato nadut petel (lit. as fat as a pompous rooster); Bulg. debel kato svinya (lit. as fat as a swine); Bulg. debel kato prase (lit. as fat as a pig); Bulg. debel kato slon (lit. as fat as an elephant); Bulg. debel kato tyulen (lit. as fat as a sea calf); Bulg. debel kato hippopotam (lit. as fat as a hippo); Bulg. debel kato krava (lit. as fat as a cow); Bulg. kraven kato popova svinya (lit. as bloody as a priest's swine); Bulg. naklal se kato shopar (lit. has guzzled as a hog); Bulg. naklal se kato bik (lit. has guzzled as a bull); Bulg. palen kato bik (lit. fat as a bull); Bulg. tanak kato svinya /iron./ (lit. as thin as a swine); Bulg. ugoen kato dunavska svinya (lit. fattened as a Danube swine); Rus. kak begemot tolstyi (neukliuzhii) (lit. as thick as a hippopotamus); Rus. kak svin'ia tolstyi (zhirnyi) (lit. as fat as a hog); Rus. zhirnyi (tolstyi) kak porosenok (lit. as plump as a young hog); Rus. tolsty kak svinya (lit. as fat as a swine); Rus. rassheperit'sia kak korova (lit. to sit like a cow /dial./); Rus. bol'shaia (tolstaia) kak korova (lit. as big (fat) as a cow); Rus. raz'est'sya kak doinaia korova (lit. to grow fat as a milch-cow /disappr./); Rus. raspuzit' kak korova (to get belly like a cow /dial./); Rus. tolstaya (raskormlennaia) kak korova, bol'shoi (tolstyi) kak korova (lit. as fat (fatten) as a cow /disdain./); Rus. tolstaya (raskormlennaia) kak korova (lit. to fatten as a cow /dial./); Rus. zhirnyi (tolstyi) kak (slovno, tochno) svinya (lit. as fat (big) as a pig); Rus. zhiret' razzhiret' kak (slovno, tochno) svinya (lit. to run to fat (fatten) like a pig); Rus. devka iadra kak korova (lit. the girl as robust as a cow /dial./); Rus. zdorova kak korova (lit. as strong as a cow); Rus. zdorovyi (ogromnyi, gruznyi) kak slon (lit. as big (huge, stodgy) as an elephant).

2) Leanness, meagerness

An excessive human leanness, in the finest details is presented in the Bulgarian and Russian languages-Bulg. slab (marshav, tanak, suh) kato chiroz (lit. as thin (skinny, lean, meagre) as dried herring); Bulg. slab (tanak, suh) kato glist (lit. as thin (fine, meagre) as a helminth); Bulg. slab (tanak, suh) kato komar (lit. as thin (lean, meagre) as a mosquito); Bulg. slab (tanak, suh) kato shtiglets (lit. as thin (lean, meagre) as a goldfinch); Bulg. slab (tanak, suh) kato skarida (lit. as thin (lean, meagre) as a shrimp); Bulg. slab (marshav) kato chervei (lit. as weak (meagre) as a worm); Bulg. slab (marshav) kato payak (lit. as thin (meagre) as a spider); Bulg. marshav kato pastarma (lit. as meagre as jerk); Bulg. marshav kato garvan (lit. as meagre as raven); Bulg. Marshav kato garga (lit. as meagre as a crow); Bulg. marshav kato tsarkovna mishka (lit. as meagre as a church mouse); Bulg. slab kato tankovana gaska (lit. as think as a lean goose); Bulg. such kato pechen zayek (lit. as dried as a fried rabbit); Bulg. izsahnal kato zmiya na tran (lit. as dried as a snake on a thorn); Rus. kak dokhlaia koshka (lit. like a dead cat); Rus. kak parshivaia (sheludivaia) koshka (lit. as thin as a mangy/scabby/ cat); Rus. obodrannaia kak koshka (lit. waif-like); Rus. khudoi (toshchii) kak glist/glista (lit. as thin (skinny) as a belly worm); Rus. khudoi (toshchii, obodrannyi) kak oblezlyi (dranyi, obodrannyi) kot (lit. thin (lean, scabby) like a dinky (skinned) cat /scornf./); Rus. khudoi (toshchii, shchuplyi) kak kotenok (lit. as lean (skinny, scrawny) as a kitten /disappr./); Rus. pokhudat' kak baran (lit. to thin down like a sheep /dial./); Rus. slabyi kak tsyplenok (lit. as weak as a chicken /colloq., dial./); Rus. kak glista $v$ korsete (lit. like a belly worm in a corset).

\section{3) Leanness, slenderness}

Zoomorphic figurative comparisons conveying human leanness as man slender appearance are less represented in the Bulgarian and Russian linguocultures-Bulg. tyalo kato na riba (ribka) (lit. a fish-like body (corpuscle)); Bulg. tanak kato zmiya (lit. as thin as a snake); Bulg. tanak kato chervei 
(lit. as thin as worm); Rus. tonkii (dlinnyi) kak glist/glista (lit. thin (long) like a belly worm); Rus. khudoi (tonkii) kak glist (lit. as lean (thin) as a belly worm).

\section{S. Perception of Appearance}

\section{1) Tallness}

An extremely high human height, conveyed by the zoomorphic figurative comparisons, is presented in the Russian linguoculture in great details-Rus. vysokii kak zhiraf (lit. as tall as a giraffe); Rus. dlinnyi kak zhiraf (lit. as long as a giraffe); Rus. dlinnonogii (dlinnyi) kak tsaplia (lit. as long-legged (long) as a heron); Rus. dlinnonogii kak aist (lit. as long-legged as a stork); Rus. dlinnyi (dolgoviazyi) kak aist (lit. as long (weedy) as a stork /colloq., dial., neglect./); Rus. dlinnyi (dolgoviazyi) kak zhuravl' (lit. as long (weedy) as a crane /neglect./); Rus. dlinnonogii kak zhuravl' (lit. as long-legged as a crane Ineglect./); Rus. dlinnyi (dolgoviazyi) kak tsaplia (lit. as long (weedy) as a heron /jokingly-ironic./); Rus. dlinnyi kak cherviak (lit. long like a worm); Rus. dlinnyi kak kalist (lit. as long as a stork /dial., jokingly-ironically/); Rus. tsybatyi (dlinnobudylyi) kak zhuravel' (lit. as leggy as a crane /dial., iron./); Rus. dlinnyi kak cherviak (lit. as long as a worm /colloq., disdain. /); Rus. dlinnyi (dlinniushchii) kak gad (lit. as long (looong) as a reptile /dial./). An overly tall girl the Russians compare to a loon: Rus. vytianut'sia kak gagara (lit. to grow like a loon). The Bulgarian lexicographic sources discover just one zoomorphic figurative comparison conveying the extreme height-Bulg. visok kato zhiraf (lit. as tall as a giraffe).

\section{2) Shortness}

The Russian lexicographic sources identify only one zoomorphic figurative comparison presenting man's shortness, moreover, it is related to children (Rus. malen'kii kak kotenok (lit. small like a kitten /dial. /), while there are no such comparisons related to man's short stature in the Bulgarian sources at all.

\section{T. Gait}

\section{1) A beautiful gait}

Man's elegant gait is fixed to a limited extent both in the Bulgarian and Russian zoomorphic figurative comparisonsBulg. viya se (izvivam se) kato zmiya (lit. to twist (wriggle) like a snake); Bulg. stapva kato kotka (lit. walks like cat); Rus. pokhodka kak u kota (lit. cattish gait); Rus. khodit' korol'kom (to strut like a kingling /dimun., dial./).

\section{2) An awkward gait}

Human awkward gait is mainly fixed in the Bulgarian zoomorphic figurative comparisons - Bulg. hodya kato hamata kokoshka; (lit. to walk like a lame hen); Bulg. varvya kato mechka (lit. to walk like a bear); Bulg. hodya kato koza na led (lit. to walk as a goat on ice); Bulg. varvya kato kaorova patka (lit. to walk as a bat-eyed duck); Bulg. varvya kato spanat kon (lit. to walk as a hobbled horse); Bulg. varvya kato kaorav kon v turski grobishta /dial./); (lit. to walk as a bat-eyed horse in Turkish graveyard); Bulg. viya se kato zmiya $v$ koshnitsa /dial. / (lit. to wriggle as snake in a basket); Bulg. viya se kato zmiya u protsep /dial./ (lit. to wriggle as a snake in a crack); Bulg. vlacha se (makna se, hodya) kato prebita zmiya (lit. to crawl (drag alone, walk) as a beaten snake); Bulg. vlacha se kato prebito kuche (lit. to drag on like a beaten dog); Rus. khodit' kak kuritsa mokhnonogaia (lit. to walk like a feather-footed hen).

3) An energetic gait

The horse is associated with man's energetic gait both in the Bulgarian and Russian linguocultures- Bulg. hodya kato kon (lit. to walk like a horse)- Rus. skakat' kak loshad' (lit. to galop like a horse); Bulg. pargav kato sarna (lit. nimble as a doe).

4) A cautious gait

A cautious gait in the Bulgarian linguoculture is associated with a walk of a donkey on ice: Bulg. stapvam kato podkovano magare na led (lit. to step as a shod donkey on ice).

\section{U. Odor}

In the Bulgarian and Russian linguocultures stale odor is associated with a smelly polecat or a billy goat-Bulg. smardya (vonya, mirisha) kato por (lit. to stink (smell) as a polecat) - Rus. voniuchii kak khor' (khorek) (lit. smelly like a polecat); Bulg. vonya (smardya, mirisha) kato prach (lit. to stink (smell) as a billy goat) - Rus. voniaet kak ot kozla (lit. smells like a billy goat).

\section{Tenderness, Fragility}

In the Bulgarian and Russian linguocultures man with light weight or not feeling one's own weight is compared to a feather and plume-Bulg. lek jato pero (pertse) (lit. as light as a feather /plumelet/) - Rus. legkii kak pero /peryshkol (lit. as light as a feather /plumelet/); Bulg. lek kato perushina (perushinka) (lit. light as plumage) - Rus. legkii kak pushinka (pushinochka, pukh) (lit. as light as plumelet/fluff/). The Bulgarians also associate man having light weight with a dove's egg-Bulg. krehak (nezhen) kato gurgulovo yaitse (lit. as fragile (tender) as a dove's egg).

\section{W. Beautiful Appearance}

The Bulgarians associate man's beautiful looks with a decorated egg and the bird of paradise-Bulg. hubav kato pisano yaitse (lit. as beautiful as painted egg), Bulg. krasiva kato raiskaya ptitsa (lit. as beautiful as a bird of paradise). The Russian lexicographic sources do not show any zoomorphic figurative comparisons with this attribute 'beautiful'.

\section{Ugliness}

Human ugliness in the Bulgarian linguoculture is compared to a bulldog or a boar, a monkey, an orangutan, a gorilla, a polecat, a frog (toad), a magpie, an owlet and a crocodile- Bulg. grozen kato buldog (lit. as ugly as a bulldog); Bulg. grozen kato gligan (lit. as ugly as a boar); Bulg. grozen kato maimuna (lit. as ugly as a monkey); Bulg. grozen kato orangutan (lit. as ugly as an orangutan); Bulg. grozen kato gorila (lit. as ugly as a gorilla); Bulg. grozen kato por (lit. as ugly as a polecat); Bulg. grozen kato zhaba (lit. as ugly as a toad); Bulg. grozen kato svarka (lit. as ugly 
as a magpie); Bulg. grozna kato kukumyavka (lit. as ugly as an owlet); Bulg. grozna kato krokodil (lit. as ugly as a crocodile); Bulg. hubav kato prase v pumiya /ironic/ (lit. as handsome as a pig in slops). Moreover, among the Bulgarian zoomorphic figurative comparisons, reflecting man's plain appearance, there are alogical expressive figurative comparisons-Bulg. krasiv kato gushter, ugly '(lit. as beautiful as a lizard); Bulg. krasiv kato nastapan chervei ,plain" (lit. as handsome as a downtrodden worm); Bulg. krasiv kato ameba ,plain' (lit. as beautiful as an amoeba); Bulg. krasiva kato darta maimuna 'plain' (lit. as beautiful as an old monkey). In Russian linguoculture man's plain appearance is also compared to a beast (Rus. nekrasiv chto zver' (lit. as ugly as a beast /dial., disappr./), a plain, with disproportionately long arms and legs, helplessly looking child - with a frogling (Rus. rebenok kak liagushonok (lit. child like a frogling /dimin.-pejor., or ironic/), and an extremely ugly and (often) elderly woman - to a grey mare (Rus. krasiva kak kobyla siva (lit. as beautiful as a grey mare /folk., ironic./)

\section{Y. Gaudy, Incompatible, Unsuitable, Stained Clothing}

Gaudy, colorful, incompatible, stained clothing is more widely described in the Russian figurative comparisonsBulg. mrasen kato prase (lit. as dirty as a pig); Bulg. kato (ko) dermendzhiiska machka /dial./ (lit. as a miller's cat); Rus. odet'sia (nariadit'sia) kak pavlin (lit. to dress (up) like peacock); Rus. odet'sia (nariadit'sia) kak popugai (lit. to dress (up) like a parrot); Rus. kak korova iazykom liznula kogo (lit. as if licked by cow /dial., disappr./); Rus. griaznyi kak svin'ia (porosenok) (lit. as dirty as a pig /piglet/); Rus. khodit' kak porosenok (lit. to go about like a piggy /colloq., dial., pejor./).

A well-dressed but penniless man in the Russian linguoculture is subject to quizzical criticism discussion/Rus. krutoi kak dva yaitsa v kastriul'ke (lit. tough as two eggs in a saucepan /slang, iron,/) '1) about a well-dressed but unmoneyed man, 2) about man trying to look tough'; Rus. krutoi kak porosiachii khvostik (lit. as tough as a pig tail /slang, iron./) '1) about a well-dressed but unmoneyed man, 2) about man trying to look tough'.

\section{CONCLUSION}

Culture code is a semiotic system wherein the set of national ethnocultural information is concentrated, coded in the form capable of identifying culture through the complex of secondary signs and symbols endowed with such senses. The zoomorphic culture code, as part of the linguistic world landscape, reflects the value system of certain linguocultures.

The comparative study of the zoomorphic culture code in the semantics of the Bulgarian and Russian figurative comparisons, representing human appearance, has identified the following relationship types:

- The relationship of the complete structural-semantic equivalence (coincidence of the tertium comparationis and the standards (images) in the languages compared): Bulg. debel kato prase (lit. as fat as a pig) - Rus. zhirnyi (tolstyi) kak porosenok (lit. as fat (big) as a pigling). Those relations are due to the sameness of mentality and observations of the two linguocultures' members.

- The relationship of the structurally similar but semantically different zoomorphic figurative comparisons: comp. Bulg. slab (tanak, suh) kato glist (lit. as thin (fine, meagre) as a helminth), about a very airy (skinny, slim) man'; Rus. khudoi (toshchii, tonkii) kak glist/glista (lit. as lean (slim) as a helminth) , about a very slim and extremely tall man'; Rus. tonkii kak glista (lit. as lean as a helminth) , about a thin, bareboned and pale man'; this relationship type has been produced by various accentuation of attributes under the coincidence of the selected images. The lexicographic sources do not always register the identified nuances of meanings. Decoding of the subtleties of meanings sometimes materializes only after a thorough study of the figurative comparisons functioning in speech.

- The coincidence of the tertium comparationis where the chosen reference standards differ. This type of relationship suggests that different pivotal images of comparison are established in different languages as a result of the particularities of world perception in different cultures (Bulg. pobelyal kato ovtsa (lit. as white as sheep) - Rus. bel/bela kak lun' (lit. as white as a harrier); Rus. sedoi kak lun' (lit. as grey as a harrier).

- Divergence of the tertium comparationis and the corresponsing reference standard. This type of relationship implies that zoomorphic figurative comparisons are specific only to one language, namely they do not have equivalents in the compared linguocultures, in the absence of corresponding associative bond between the tertium comparationis and the comparative part (Bulg. opulil ochi kato zhabche $v$ tinya /dial./ (lit. to widen eyes like a frog in ooze); Bulg. zhalt kato papunyak (lit. as yellow as hoopoe); Rus. rot kak u liagushki (zhaby) (lit. a froglike mouth); Rus. rot kak u shchuki (lit. a toad-like mouth); Rus. rot kak u soma (lit. a catfish-like mouth); Rus. rot kak u nalima (lit. a jackfish-like mouth). That fact proves thought of F. N. Guketlova that the zoomorphic codes in certain languages, tending to preserve universal features, are distinguished by the national distinctness [18].

In the Bulgarian and Russian linguocultures domestic animals' images are more often associated with human appearance. This may be explained by the fact that domestic animals since ancient times were the companions of man in his daily life.

Along the analysis of the zoomorphic figurative comparisons that we have collected, it has been found that in the Bulgarian and Russian linguocultures dominate figurative comparisons describing the negative characteristics of human appearance (such as fatness /Rus. rassheperit'sia kak korova (lit. take seats like a cow/ (dial.) 'about a very stout, massive woman, baring the way; Rus. 
raz'es'sya kak doinaia korova /disappr/ (lit. to grow fat as a milch-cow /disappr./) , about a very big and stout woman'; Rus. raspuzit' kak korova (lit. to get belly like a cow /dial., disappr./) 'about too fatten man (especially woman)'; Rus. bol'shoi (tolstyi) kak korova (lit. as big (fat) as a cow /disappr./) 'about a fat, bid-sized woman'; Rus. tolstaia, raskormlennaia kak korova (lit. as fat (fattened) as a cow /disdain./) 'about a fat, bid-sized woman'; Rus. tolstet' kak korova (lit. to fatten like a cow /dial., disappr./) 'about a woman growing stout'; Rus. zhirnyi (tolstyi) kak (slovno, tochno) svin'ia (lit. as fat (big) as (like) a pig /disdain./) '1) about a stout man, 2) about a dirty man'; Rus. zhiret' razzhiret' kak (slovno, tochno) svin'ia (lit. to run to fat (fatten) as (like) a pig); Rus. devka yadra kak korova (lit. the girl is robust as a cow /dial./) 'about a big, full-blooded girl'/ an excessive human leanness, meagerness /Bulg. izsahnal kato zmiya na tran (lit. as dried as a snake on a thorn), extremely withered, gaunt'; Rus. khudaia (khuda, toshchaia, toshcha, obodrannaia, obodrana) kak dranaia (oblezlaia) koshka (lit. thin (gaunt, dinky) like a tattered (dinky) cat) 'about an unwholesomely thin, gaunt, pathetic, worn woman; Rus. kak zmeya $v$ korsete (lit. like a snake in corset) 'about a thin and malicious woman'; Rus. kak sel'd'v korsete /dial./ (lit. as a herring in corset) 'about a raw-boned woman'\%, pale complexion /Bulg. zhalt kato papunyak (lit. as yellow as hoopoe)/, painful appearance, weakness /Rus. glaza krasnye kak u krolika (lit. the eyes are red as a rabbit) 'about red yes from overwork, insomnia, tears, excessive drinking or sickness'\%, incompatible, unsuitable, stained clothing /Rus. odetyi kak popugai (lit. dressed (up) like a parrot) 'about a person (often a man) dressed in colors, frumpishly'; Rus. boltat'sia kak iaitso v prorubi na kom (lit. to hang loose like an egg in an ice-hole) 'about too loose clothes; Rus. napudrilas' kak korova riabilas' /iron., disdain./ (lit. powdered her face like spruced cow) 'about too much and tastelessly painted girl'/ etc.), while the figurative comparisons, displaying positive appearance details (doe instance, beauty /Rus. dlinnaya (krasivaya) kak u lebedya sheya (lit. long (beautiful) swanneck 'about girl's fine neck'), fine manner of walking /Rus. nogi u kogo kak u lani (bookish-poetic/) (lit. feet like of a fallow deer) 'about a slender young girl's nifty and quick legs \%, grace /Bulg. tyalo (teltse) kato na riba (ribka) (lit. fish-like body), about a slender person'; Rus. kak lebedka belaia /dial., folk., sympath./ (lit. like a white swan) 'about a very beautiful, white-faced and slender girl (usually princess, etc.)'/ and so on) are less frequent. This is explained by the fact that nominations falling outside the conventional beliefs about presentable appearance require figurative marking.

With the apparent dissimilarities, we arrive at the conclusion about the existence of similarity in the imageevaluation system of human appearance in the Russian and Bulgarian linguocultures. This results from the universality of human nature, on the one hand, and from the common Indo-European roots and the two languages' belonging to the European linguocultural community, on the other. In this sense one cannot agree more with what has been said by D. G. Maltseva that "the similarity and identity of thought is not surprising, since the basic concepts of morality, the ideas of good and evil, the dictates of common sense and the conclusions of empirical observations of the nature and skills of animals are more or less identic for all nations" [19].

The analysis of the zoomorphic figurative comparisons, reflecting human appearance, helps to better understand and correlate the values structure in the Bulgarian and Russian linguocultures.

\section{REFERENCES}

[1] R. Stoyanova, Bulgarian and Russian Zoomorphic Figurative Comparisons Reflecting Human Appearance. ASSEHR: Advances in Social Science, Education and Humanities Research, Paris: Atlantis Press, 142, 2017, pp. 403 - 406

[2] R. Stoyanova, Zoomorphic Cultural Codes in the Semantics of Bulgarian and Russian Similes, ASSEHR: Advances in Social Science, Education and Humanities Research, Paris: Atlantis Press, 122, 2017, pp. 520 - 525.

[3] M. L. Kovshova, Linguoculturological method in phraseology: Culture codes. Moscow: LENAND, 2016. 456 p., p. 169.4 Ibid 7,170 .

[4] E. S. Kubryakova, About the semiotically marked objects and semantically marked situations in a language // Conceptual Sprachraum. Proceedings. Dedicated to the anniversary of Prof. N. N. Boldyrev. Tambov: G.R. Derzhavin TGY Press, 2005, pp. 95-101.

[5] Yu. S. Stepanov, In the world of semiotics // Semiotics. Anthology / ed. Yu. S. Stepanov, V.V. Feshchenko. Moscow, Yekaterinburg, 2001, pp. 5-42.

[6] M. L. Kovshova, Linguoculturological method in phraseology: Culture codes, p. 170

[7] V. V. Krasnykh, Dictionary and grammar of linguoculture; The fundamentals of pshycholinguoculturology. Moscow: Gnosis Publishing House, 2016. 496 p., p. 379.

[8] V. V. Krasnykh, Foreign native: myth or reality? Moscow: Gnosis, 2003. 375 p., p. 297-310.

[9] V. V. Krasnykh, The elements of psycholinguistics and communicology. Moscow: Gnosis Publishing House, 2001. 270 p., p. 138 .

[10] V. V. Krasnykh, Dictionary and grammar of linguoculture; The fundamentals of pshycholinguoculturology, p. 379.

[11] V. N. Telia, Priorities and methodological problems of the study of phraseological composition of language in the context of culture // Phraseology in the context of culture. Moscow: Languages of Russian Culture, 1999, pp. 20-21.

[12] V. N. Telia, Russian phraseology: Semantic, pragmatic and liguoculturological aspects. Moscow: Languages of Russian Culture, 1996. 288 p., p. 243.

[13] V. V. Krasnykh, Dictionary and grammar of linguoculture; The fundamentals of pshycholinguoculturology, pp. 131, 379-380.

[14] V. V. Krasnykh, Ethnopsycholinguistics and linguoculturology: Course of lectures. Moscow: Gnosis Publishing House, 2002. 284 p., p. 256.

[15] L.V. Savchenko, Model of substantive culture codes (using phraseosystems of the Russian and Ukrainian languages // Culture of the people of The Black Sea Region, No. 275, Simferopol, p. 176.

[16] V. A. Maslova, M.V. Pimenova, Codes of linguoculture: guide. M.: FLINTA: Nauka, 2016. 180 p., pp. 13-117.

[17] B. Yanev, B. Yanev, Figurative comparisons with anthropocentric nature in the Bulgarian and English languages (research and dictionary). Plovdiv: "Paisius of Hilendar" University Press, 2013, 370 p., pp. 14-117.

[18] F. N. Guketlova, Zoomorphic culture code in the linguistic landscape (using the materials of the French, Kabardino-Cherkess and Russian languages). Extended abstract of Cand. Sci.: 10.02.02. M., 2009. 431 p., p. 12 . 
[19] D. G. Maltseva, Phraseological units of the German language in the country-oriented linguistic context and the translation problems: (Handbook) / D. G. Maltseva; All-Russian Centre for Translation of Scientific and Technical Literature and Documentation. Moscow: AllRussian Centre for Translation, 1993. 134 p., p. 14. 